Oleh: Muhammad Auza'i Aqib

\title{
ANALISIS LEVEL BERPIKIR GEOMETRI GURU MI DITINJAU DARI JENIS KELAMIN
}

\author{
Mohammad Auza'i Aqib \\ Institut Agama Islam Tribakti Kediri \\ auzaioke@yahoo.com
}

\begin{abstract}
One of the scopes of mathematical material for MI is geometry and measurement. So many competencies related to geometry for basic education units are their own difficulties for students. The students' difficulties in learning geometry is certainly a challenge for teachers who are given the task of teaching the subjects concerned. In essence, the teacher must have professional competence where the teacher must master the material taught. The level of mastery of the material especially geometry can be seen from the level of thinking of Van Hielle's teacher. This study aims to describe the level of thinking of male and female MI teachers. This type of research is a descriptive study with a qualitative approach. The subjects in this study were male and female MI teachers who both taught class VI to avoid bias. The instruments in this study were the researchers themselves and test-based interview guidelines. The test given is adapted from V.H.G.T (Van Hielle Geometry Test). Data processing is done by reducing data, presenting data, and drawing conclusions. The results showed that the level of thinking of male MI teacher geometry was at level 0 while the level of thinking of the geometry of female MI teachers was at level 2.
\end{abstract}

\begin{abstract}
Abstrak
Salah satu ruang lingkup materi matematika untuk MI adalah geometri dan pengukuran. Begitu banyaknya kompetensi yang berhubungan dengan geometri untuk satuan pendidikan dasar merupakan kesulitan tersendiri bagi siswa. Kesulitan siswa dalam mempelajari geometri tersebut tentu menjadi tantangan tersendiri bagi guru yang diberikan tugas mengampu mata pelajaran yang bersangkutan. Pada hakekatnya guru harus memiliki kompetensi profesional dimana guru harus menguasai materi yang diajarkan. Tingkatan penguasaan materi khusunya geometri dapat dilihat dari tingkatan level berpikir Van Hielle guru tersebut. Penelitian ini bertujuan untuk mendeskripsikan tingakatan level berpikir guru MI laki-laki dan perempuan. Jenis penelitian ini merupakan penelitian deskriptif dengan pendekatan kualitatif. Subjek dalam penelitian ini adalah Guru MI laki-laki dan
\end{abstract}


perempuan yang sama-sama mengampu kelas VI agar menghindari adanya bias. Instrumen dalam penelitian ini adalah peneliti sendiri dan pedoman wawancara berbasis tes. Tes yang diberikan diadaptasi dari V.H.G.T (Van Hielle Geometry Test). Pengolahan data dilakukan dengan cara reduksi data, penyajian data, dan penarikan simpulan. Hasil penelitian menunjukkan bahwa tingkat berpikir geometri guru MI lakilaki adalah pada level 0 sedangkan tingkat berpikir geometri guru MI perempuan adalah pada level 2 .

Kata Kunci : Level Berpikir Geometri, Guru MI, Jenis Kelamin

\section{Pendahuluan}

Terdapat beberapa tingkatan dalam satuan pendidikan. Menurut Permendikbud (2018), satuan pendidikan di Indonesia terdiri dari tingkatan dasar dan menengah meliputi Sekolah Dasar (SD), Madrasah Ibtidaiyah (MI), Sekolah Menengah Pertama (SMP), Madrasah Tsanawiyah (MTs), Sekolah Menengah Atas (SMA), Madrasah Aliyah (MA), dan lain sebagainya. Pemerintah telah membuat aturan untuk memberikan layanan pendidikan sampai tamat satuan pendidikan menengah atau bisa dikenal dengan wajib belajar 12 tahun (Permendikbud, 2016).

Diantara keseluruhan mata pelajaran, terdapat mata pelajaran yang selalu diajarkan disetiap satuan pendidikan yaitu matematika. Matematika merupakan salah satu cabang ilmu pengetahuan yang cara pembelajaranya dilakukan secara bertingkat. Dalam hal ini bearti materi matematika yang diajarkan pada satuan pendidikan untuk tingkatan menengah pasti tidak akan bisa berjalan bila hal-hal terkait matematika yang diajarkan pada tingkatan dasar tidak betul-betul dipahami oleh siswa. Tingakatan dasar dalam hal ini mencakup jenjang pendidikan Sekolah Dasar (SD)/ Madrasah Ibtidaiyah (MI). Kompetensi Inti dan Kompetensi Dasar yang ditetapakan pemerintah melalui permendikbud untuk satuan SD dan MI adalah sama. Hal ini mengindikasikan bahwasanya cakupan materi matematika yang diajarkan di MI barang tentu sama dengan yang diajarkan di SD.

Sejatinya materi matematika memiliki cakupan sebanyak 4 ranah area (Shiel, 2007). Empat ranah tersebut antara lain: space \& shape, change \& relationships, quantity, dan uncertainty. Space \& shape berkaitan tentang pengenalan dan pemahaman pola geometri dalam identifikasi pola abstrak serta representasinya di dunia nyata. Selanjutnya change \& 
Oleh: Muhammad Auzäi Aqib

relationship berkaitan tentang seperti yang tertuang dalam pemahaman hubungan antara permendikbud (2016) antara lain: variabel dan tentang istilah dalam berbagai bentuk antara lain: simbol, aljabar, grafik, dan tabel. Kemudian quantity yaitu pemahaman tentang ukuran relatif, pengenalan pola bilangan dan penggunaan angka untuk merepresentasikan data kuantitatif di dalam objek dunia nyata. Terakhir yaitu uncertainty adalah tentang penyelesaian masalah berkaitan dengan data dan peluang. Dari keempat ranah tersebut, kesemuanya pasti diajarkan pada satuan pendidikan dasar terlebih dahulu sebut saja pada ranah space \& shape. Pada ranah space \& shape untuk satuan pendidikan dasar siswa diharuskan mengenali dan memahami bentuk objek 2 dimensi, objek 3 dimensi, serta cara menggambar objek 2 maupun 3 dimensi tersebut. Pemerintah sendiri melalui permendikbud (2016) membagi ruang lingkup materi matematika untuk MI yaitu antara lain: bilangan asli dan pecahan, geometri dan pengukuran, dan statistika. Berbicara tentang geometri tentu terdapat kaitan yang erat dengan ranah area space \& shape. Hal ini dikarenakan kompetensi yang berhubungan dengan geometri juga termasuk ranah space \& shape. Kompetensi yang berhubungan dengan geometri mengelompokkan benda menurut kelompoknya, mengelompokkan benda menurut bentuk dan justfikasinya, mengelompokkan bangun ruang menurut sifatnya, dan lain sebagainya.

Begitu banyaknya kompetensi yang berhubungan dengan geometri untuk satuan pendidikan dasar tentu memberikan kesulitan tersendiri bagi siswa. Hal ini tidak terlepas dari keabstrakan geometri yang notabene merupakan cabang dari matematika. Seperti yang diungkapkan Soedjadi (dalam Muhsetyo, 2007) bahwa keabstrakan matematika karena objek dasarnya abstrak, yaitu fakta, konsep, operasi, dan prinsip. Dimana ciri keabstrakan matematika beserta ciri lainya menyebabkan matematika tidak mudah untuk dipelajari yang pada akhirnya banyak siswa kurang tertarik terhadap pelajaran tersebut.

$$
\text { Kesulitan siswa dalam }
$$
mempelajari geometri tersebut tentu menajadi tantangan tersendiri bagi guru yang diberikan tugas mengampu mata pelajaran yang bersangkutan. Pada hakekatnya guru harus keempat kompetensi, yakni kompetensi pedagogik, kompetensi kepribadian, kompetensi sosial, dan kompetensi profesional (UU RI No. 14 tahun 2005 tentang Guru dan Dosen). Dimana pada kompetensi 
profesional, guru harus menguasai materi yang diajarkan. Hal ini mengindikasikan bahwa ketika hendak membelajarkan materi geometri kepada siswa, guru juga harus memiliki pengetahuan yang mendalam terhadap materi geometri tersebut.

Pengetahuan dalam materi geometri sejatinya memiliki beberapa tingakatan seperti yang dikemukakan dalam teori Van Hielle. Teori Van Hielle menyatakan bahwa eksistensi dari lima tingkatan yang berbeda tentang pemikiran geometrik, yaitu (a) level 0 (visualisasi), (b) level 1 (analisis), (c) level 2 (deduksi informal), (d) level 3 (deduksi), dan (e) level 4 (rigor) (Muhsetyo, 2007)

\section{Level 0}

Menurut Musser, Burger, and Petterson (2011) cakupan level 0 yaitu memandang bangun secara holistik atau apa adanya tanpa memperhatikan unsur-unsur didalamnya.

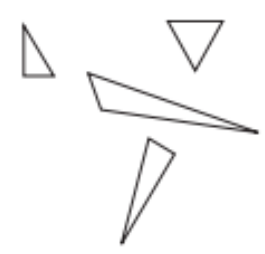

Gambar 1 Ilustrasi Level 0

Contohnya yaitu ketika seseorang yang berada di level 0 , maka akan memandang gambar 1 bukan sebagai segitiga walaupaun pada hakikatnya gambar 1 tersebut merupakan gambar segitiga.

\section{Level 1}

Menurut Musser, Burger, and Petterson (2011) cakupan level 1 yaitu memandang suatu bangun secara analitis pada bagian-bagianya, seperti dari sudut atau sisinya.

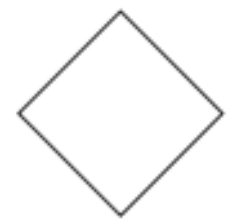

Gambar 2 Ilustrasi level 1

Contohnya yaitu ketika seseorang berada di level 1, maka akan memandang gambar 2 merupakan persegi walaupun posisinya dimiringkan. Asalkan suatu bangun memenuhi unsur persegi yaitu semua sisinya sama panjang dan semua sudutnya siku-siku walaupun di putar tetap merupakan persegi.

\section{Level 2}

Menurut Musser, Burger, and Petterson (2011) cakupan level 2 yaitu memahami hubungan antar bangun secara abstrak.

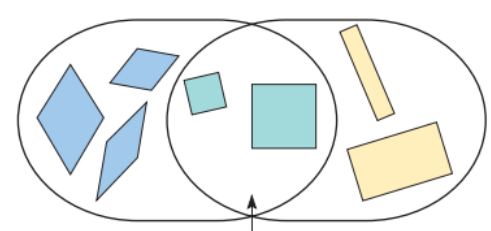

Gambar 3 Ilustrasi level 2 
Ketika seseorang berada pada level 2, maka akan memahami ilustrasi dari gambar 3. Bahwasanya antara bangun belah ketupat, persegi, dan persegi panjang memiliki suatu keterikatan. Dari gambar terlihat bahwa bangun persegi juga merupakan bangun belah ketupat. Bisa diartikan bahwa persegi merupakan belah ketupat khusus dimana terdapat syarat tambahan yaitu kesemua sudutnya siku-siku. Demikian halnya persegi dan persegi panjang. Persegi bisa dikatakan persegi panjang yang memiliki aturan khusus, yaitu kesemua sisinya memiliki panjang yang sama.

\section{Level 3}

Menurut Musser, Burger, and Petterson (2011) cakupan level 3 yaitu memahami penggunaan postulat dan teorema dalam matematika dan dapat menulis pembuktian suatu teorema. Contoh seseorang masuk di level 3 adalah ketika bisa membuktikan teoram sudut dalam segitiga yang memiliki besar kurang dari atau sama dengan $180^{\circ}$.

\section{Level 4}

Menurut Musser, Burger, and Petterson (2011) cakupan level 4 yaitu pemahaman geometri yang sangat abstrak dan tidak membutuhkan sesuatu yang konkret. Seseorang yang memiliki pengetahuan level 4 bearti memiliki pengetahuan tertinggi tentang geometri. Orang tersebut tidak hanya dapat membuktikan teorema, tetapi mengerti betul alasan penggunaan aksioama yang menjadi dasar pembuktian teorema tersebut.

\section{Metode Penelitian}

Jenis penelitian yang digunakan dalam penelitian ini adalah deskriptif kualitatif. Penelitian ini bertujuan untuk mendiskripsikan level berpikir guru MI ditinjau dari jenis kelamin. Instrumen penelitian yang digunakan terdiri dari Instrumen utama dan pedukung. Instrumen utama adalah peneliti sendiri. Sedangkan instrumen pendukung berupa pedoman wawancara berbasis tes. Tes yang diberikan diadaptasi dari V.H.G.T (Van Hielle Geometry Test). Tes yang digunakan berupa tes pilihana ganda dengan opsi jawaban sebanyak 5 pilihan. Banyaknya butir tes adalah berjumlah 5 butir soal dengan setiap satu soal mewakili tiap tahapan level berpikir. Format pengisian tes tersebut yaitu dengan menyilang jawaban yang dianggap tepat. Teknik pemilihan subjek yang digunakan adalah dengan purposive subjek dengan kriteria guru MI yang 
Analisis Level Berpißir Geometri Guru MI Ditinjau dari Jenis Kelamin

Oleh: Muhammad Auza'i Aqib

memiliki jenis kelamin berbeda. Agar menghindari bias kedua guru MI dengan jenis kelamin berbeda dipilih berdasarkan kesamaan kelas yang diampu yaitu kelas VI. Proses pengolahan data mengacu pada Miles dan Huberman yaitu reduksi data, penyajian data, dan penarikan simpulan.

\section{Hasil Temuan dan Pembahasan Level berpikir geometri guru MI laki-laki}

Berdasarkan hasil tes diperoleh jawaban guru laki-laki MI untuk soal no. 1 seperti tertera pada gambar 4 berikut.

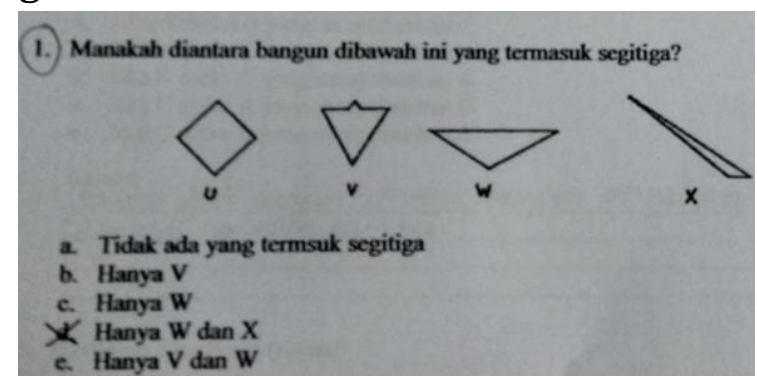

Gambar 4 Jawaban guru MI Laki-laki untuk soal no. 1

Dari gambar terlihat guru MI laki-laki memilih jawaban D. Soal no. 1 berisikan pertanyaan tentang contoh bangun segitiga. Soal tersebut mewakili permasalahan geometri untuk tingkat berpikir level 0. Dalam soal terdapat empat gambar, dimana guru diharuskan memilih dari keempat bangun tersebut yang termasuk bangun segitiga. Wawancara kemudian dilakukan untuk mengetahui alasan pemilihan opsi D. Dari wawancara diperoleh informasi bahwa guru memilih jawaban D dikarenakan pada pilihan tersebut bangun yang terlihat terdiri dari 3 sisi dan jumlah ketiga sudutnya $180^{\circ}$.

Pernyataan guru tersebut sudah sesuai dengan apa yang dikemukakan oleh Musser, Burger, and Petterson. Musser, Burger, and Petterson (2011) mengungkapkan bahwa segitiga adalah bangun yang tepat memiliki 3 segmen garis dan tiga sudut. Karena jawaban dan alasan yang dikemukakan guru sudah sesuai maka dapat ditarik kesimpulan bahwa subjek guru MI laki-laki sudah memenuhi kriteria tingkat berpikir level 0 . Muhsetyo (2007) menambahkan bahwa meskipun tidak secara langsung terkait dengan usia, siswa TK sampai dengan kelas 2 SD biasanya berada pada level 0 . Hal ini mengindikasikan bahwa guru MI laki-laki tidak akan kesulitan jika mengajarkan geometri pada kelas 1-2 MI dikarenakan cakupan materi MI dan SD adalah sama serta guru juga sudah memenuhi kriteria tingkat berpikir level 0 .

Berdasarkan hasil tes diperoleh jawaban guru laki-laki MI untuk soal no. 2 seperti tertera pada gambar 5 berikut. 


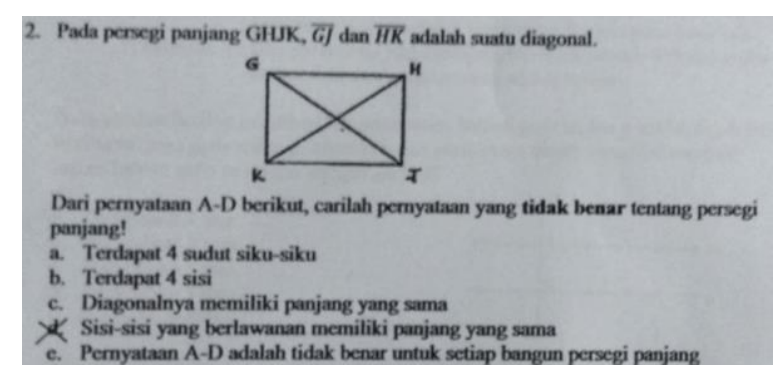

Gambar 5 Jawaban guru MI laki-laki untuk soal no. 2

Dari gambar terlihat guru MI laki-laki memilih jawaban D. Soal tersebut mewakili permasalahan geomteri tingkat berpikir level 1 . Soal no. 2 berisikan tentang pilihan pernyataan yang tidak memiliki hubungan dengan persegi panjang. Dalam soal terdapat gambar ilustrasi persegi panjang, kemudian guru diminta memilih opsi jawaban yang sesuai. Wawancara kemudian dilakukan untuk mengetahui alasan pemilihan opsi D. Dari wawancara diperoleh informasi bahwa guru memilih jawaban D dikarenakan menurut guru tersebut sisi yang berlawanan pada bangun persegi panjang memiliki panjang yang tidak sama.

Pernyataan guru tersebut tidak sesuai dengan apa yang dikemukakan oleh Musser, Burger, and Petterson. Musser, Burger, and Petterson (2011) mengungkapkan bahwa salah satu unsur persegi panjang adalah panjang sisi yang berlawanan sama panjang. Ketidak sesuaian jawaban guru dengan kunci jawaban mengindikasikan bahwa subjek guru MI laki-laki tersebut belum memenuhi kriteria tingkat berpikir level 1. Muhsetyo (2007) menjelaskan bahwa siswa SD kelas 36 biasanya berada pada level 1 . Hal ini mengindikasikan bahwa guru akan kesulitan jika mengajarkan geometri pada kelas 3-6 SD.

Berdasarkan hasil tes diperoleh jawaban guru laki-laki MI untuk soal no. 3 seperti tertera pada gambar 6 berikut.

3. Manakah yang merupakan ciri-ciri persegi panjang yang jajar genjang tidak miliki!
a. Sisi yang berlawanan sama panjang
c. Merniliki diagonal yang sama panjang
c. Sisi yang berlawanan sejajar
d: Sudut yang berhadapan sama besar
e. Tidak ada satupun dari pernyataan A-D

Gambar 6 Jawaban guru MI laki-laki untuk soal no. 3

Dari gambar terlihat guru MI laki-laki memilih jawaban B. Soal tersebut mewakili permasalahan geometri untuk tingkat berpikir level 2. Soal no. 3 berisikan pertanyaan tentang kaitan/ hubungan antara persegi panjang dan jajar genjang. Dalam soal berisi tentang unsur persegi panjang yang bukan termasuk unsur jajar genjang. Dari berbagai opsi yang ada guru diminta memilih opsi yang dirasa paling tepat. Wawancara kemudian dilakukan untuk mengetahui alasan pemilihan opsi B. Dari wawancara diperoleh informasi bahwa guru memilih jawaban B dikarenakan menurut guru tersebut jajar genjang memiliki diagonal yang tidak sama panjang berbeda dengan persegi 
Analisis Level Berpißir Geometri Guru MI Ditinjau dari Jenis Kelamin

\section{Oleh: Muhammad Auza'i Aqib}

yang memiliki panjang diagonal sama.

Pernyataan guru tersebut sudah sesuai dengan apa yang dikemukakan oleh Musser, Burger, and Petterson. Musser, Burger, and Petterson (2011) mengungkapkan bahwa unsur persegi panjang yang tidak dimiliki jajar genjang antara lain: semua sudutnya siku-siku, setiap sisinya tegak lurus, dan diagonalnya sama panjang. Sementara unsur yang dimiliki persegi panjang yang juga dimiliki oleh jajar genjang antara lain: dua pasang sisi yang berhadapan sama panjang, dua pasang sisi yang berhadapan sejajar, dan diagonalnya berpotongan pada titik tengah bangun tersebut. Walaupun pernyataan subjek guru MI laki-laki sudah sesuai dengan apa yang dikemukaan oleh para ahli. Guru belum bisa dikatakan memenuhi kriteria tingkat berpikir level 2. Van Hielle mengemukakan bahwa tingkatan level tersebut juga memiliki sifat. Salah satunya adalah fixed sequence. Maksud dari fixed sequence adalah seseorang belum bisa dikategorikan berada pada level $\mathrm{n}$ tanpa melalui level $\mathrm{n}-1$ dahulu. Dikarenakan guru belum memenuhi kriteria level 1 maka dapat disimpulkan guru belum bisa memenuhi keiteria tingkat berpikir level

2. Muhsetyo

(2007) menambahkan bahwa tingkat berpikir level 2 biasanya cocok digunakan untuk kelas 1 dan 2 SMP. Dikarenakan pada level 2 cocok digunakan untuk SMP dan bukan MI. Guru tidak akan kesulitan mengajarkan materi geometri di MI walaupun belum memenuhi kriteria level 2.

Berdasarkan hasil tes diperoleh jawaban guru laki-laki MI untuk no. 4 seperti tertera pada gambar 7 berikut.

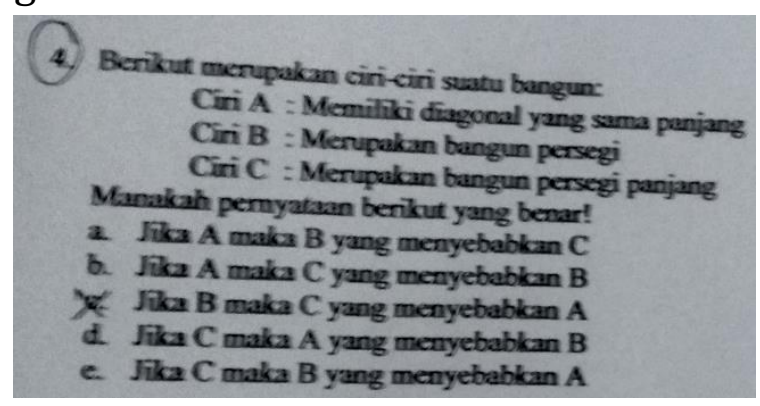

Gambar 7 Jawaban guru MI laki-laki untuk soal no. 4

Dari gambar terlihat guru MI laki-laki memilih jawaban C. Soal tersebut mewakili permasalahan geomteri untuk tingkat berpikir level 3. Soal no. 4 berisikan pertanyaan tentang membuat kesimpulan berdasarkan pernyataan-pernyataan yang tersedia. Dalam soal terdapat 3 macam ciri-ciri suatu bangun. Dari berbagai opsi yang ada guru diminta memilih opsi yang dirasa paling tepat. Wawancara kemudian dilakukan untuk mengetahui alasan pemilihan opsi C. Dari wawancara diperoleh informasi bahwa guru memilih jawaban $\mathrm{C}$ dikarenakan baik 
bangun persegi maupaun persegi panjang memiliki diagonal yang sama panjang.

Pernyataan guru tersebut sebenarnya sudah sesuai dengan apa yang dikemukakan oleh Musser, Burger, and Petterson, hanya saja kurang lengkap. Musser, Burger, and Petterson (2011) mengungkapkan bahwa persegi panjang dan persegi memiliki diagonal yang sama panjang. Hal yang kurang dari pernyataan guru tersebut adalah bahwasanya ada hubungan antara persegi panjang dan persegi. Dalam Musser, Burger, and Petterson (2011) dijelaskan bahwa setiap unsur persegi panjang juga merupakan unsur dari persegi. Sedangkan ada unsur pada persegi yang bukan termasuk unsur pada persegi panjang seperti misalnya: sisi-sisi yang berdekatan sama panjang dan diagonalnya saling tegak lururs. Dari pernyataan-pernyataan tersebut dapat ditarik kesimpulan bahwa setiap persegi pasti merupakan persegi panjang sedangkan setiap persegi panjang belum tentu persegi. Dengan pernyataan tersebut jelaslan jika suatu bangun persegi maka bangun tersebut persegi panjang. Dikarenakan pada soal tersebut berkaitan dengan level 3 dan guru belum mampu menjawab dengan lengkap maka dapat ditarik kesimpulan bahwa guru tersebut belum memenuhi kriteria tingkat berpikir level 3. Sebenarnya dalam membelajarkan geometri pada MI guru tidak perlu sampai pada tahap level berpikir tingkat 3. Hal ini seperti yang dijelaskan oleh Muhsetyo (2007) bahwa level berpikir tingkat 3 cocok digunakan untuk siswa-siswi di SMA bukan untuk MI.

Berdasarkan hasil tes diperoleh jawaban guru laki-laki MI untuk no. 5 seperti tertera pada gambar 8 berikut.

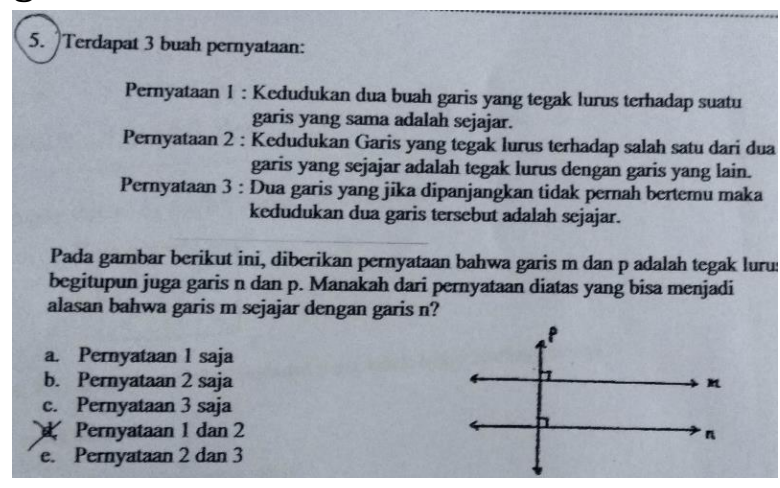

Gambar 8 Jawaban guru MI laki-laki untuk soal no. 5

Dari gambar terlihat guru MI laki-laki memilih jawaban D. Soal no. 5 berisikan pertanyaan yang berkaitan dengan level berpikir tertinggi dari van hielle yaitu tingkat berpikir level 4. Dalam soal berisi tentang berbagai pernyataan kemudian guru memilih pernyataan yang menjadi alasan munculnya suatu teorema. Wawancara kemudian dilakukan untuk mengetahui alasan pemilihan opsi D. Dari wawancara diperoleh informasi bahwa guru memilih jawaban D 
Permanent link for this document : https://doi.org/10.33367/jiee.v1i1.682

Analisis Level Berpißir Geometri Guru MI Ditinjau dari Jenis Kelamin

Oleh: Muhammad Auza'i Aqib

dikarenakan guru memiliki pendapat bahwa jika dua garis dipanjangkan maka tidak sejajar dan tidak pernah bertemu.

Pernyataan guru tersebut sebenarnya belum menjawab alasan pemilihan suatu opsi, walaupun opsi yang dijawab sudah benar. Seperti diketahui bahwa memang benar bahwa dua buah garis sejajar jika dipanjangkan maka tidak pernah bertemu. Tetapi yang ditanyakan adalah pernyataan yang mendasari hal tersebut. Jika diperhatikan, terdapat kata kunci yang mendasari suatu pernyataan dijadikan landasan dalam kesejajaran. Dalam soal diketahui bahwa garis $m$ dan $p$ adalah tegak lurus begitupun juga garus $\mathrm{n}$ dan $\mathrm{p}$. Dua pernyataan itu yang sebenarnya menjadi alasan mengapa pernyataan 1 dan pernyataan 2 merupakan jawaban yang tepat. Pernyataan 3 tidak termasuk dikarenakan tidak sesuai dengan kata kunci yang diberikan di soal. Pada dasarnya guru tidak perlu berada pada level berpikir tingkat 4 untuk mengajarkan geometri di MI hal ini seperti yang dikemukakan oleh Musser, Burger, and Petterson (2011) bahwa level 4 tidak cocok diajarkan di jenjang dasar atau pun menengah tetapi sangat cocok jika diajarkan di jenjang perguruan tinggi.

\section{Level Berpikir Geometri Guru MI}

\section{Perempuan}

Berdasarkan hasil tes diperoleh jawaban subjek guru perempuan MI untuk soal no. 1 seperti tertera pada gambar 9 berikut.

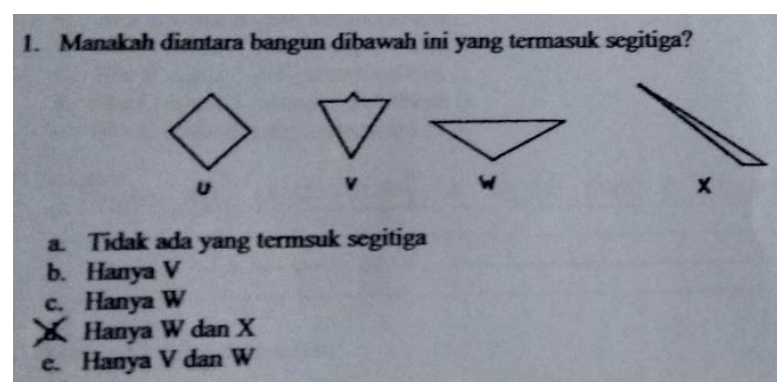

Gambar 9 Jawaban guru MI Perempuan untuk soal no. 1

Dari gambar terlihat subjek guru MI perempuan memilih opsi D. Wawancara kemudian dilakukan untuk mengetahui alasan pemilihan opsi D. Dari wawancara diperoleh informasi bahwa guru memilih jawaban D dikarenakan pada pilihan tersebut bangun yang terlihat terdiri dari 3 sisi dan 3 sudut.

Pernyataan guru tersebut sudah sangat sesuai sesuai dengan apa yang dikemukakan oleh Musser, Burger, and Petterson. Musser, Burger, and Petterson (2011) mengungkapkan bahwa segitiga adalah bangun yang tepat memiliki 3 segmen garis dan tiga sudut. Karena jawaban dan alasan yang dikemukakan guru sudah sesuai maka dapat ditarik kesimpulan bahwa guru MI perempuan juga sudah memenuhi kriteria tingkat Volume 1, Nomor 1, Maret 2019 
berpikir level 0. Muhsetyo (2007) menjelaskan bahwa meskipun tidak secara langsung terkait dengan usia, siswa TK sampai dengan kelas $2 \mathrm{SD}$ biasanya berada pada level 0 . Sesuai dengan pernyataan Muhsetyo, hal ini mengindikasikan bahwa guru MI perempuan juga tidak akan kesulitan jika mengajarkan geometri pada kelas 1-2 MI dikarenakan cakupan materi MI dan SD adalah sama serta guru juga sudah mencapai tingkat berpikir level 0 .

Berdasarkan hasil tes diperoleh jawaban guru perempuan MI untuk soal no. 2 seperti tertera pada gambar 10 berikut.

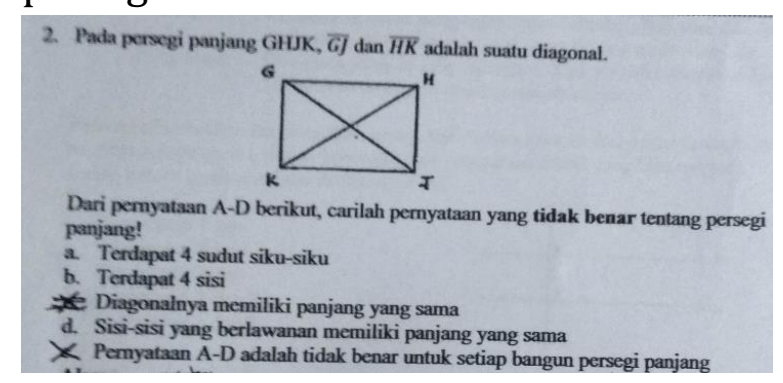

Gambar 10 Jawaban guru MI Perempuan untuk soal no. 2

Dari gambar terlihat guru MI perempuan memilih jawaban $\mathrm{E}$. Wawancara kemudian dilakukan untuk mengetahui alasan pemilihan opsi E. Dari wawancara diperoleh informasi bahwa guru memilih jawaban E dikarenakan menurut guru tersebut pernyataan a-d yang berisikan antara lain: terdapat 4 sudut siku-siku, terdapat 4 sisi, diagonalnya memiliki panjang yang sama, dan sisi-sisi yang berlawanan memiliki panjang sama, kesemuanya sesuai dengan ciri-ciri/ unsur bangun persegi panjang.

Pernyataan guru tersebut sudah sangat sesuai dengan apa yang dikemukakan oleh Musser, Burger, and Petterson. Musser, Burger, and Petterson (2011) mengungkapkan bahwa unsur persegi panjang antara lain: sepasang sisi yang berhadapan sama panjang, semua sudutnya sikusiku, sepasang sisi yang berhadapan sejajar, sisi-sisi yang berdekatan tegak lurus, kedua diagonal sama panjang, dan diagonal berpusat pada tengah bangun. Kesesuaian jawaban guru dengan kunci jawaban mengindikasikan bahwa guru MI perempuan telah memenuhi kriteria tingkat berpikir level 1. Muhsetyo (2007) menjelaskan bahwa siswa SD kelas 3-6 biasanya berada pada level 1. Hal ini mengindikasikan bahwa subjek guru perempuan MI tersebut tidak akan mengalami kesulitan jika mengajarkan geometri pada kelas 36 SD.

Berdasarkan hasil tes diperoleh jawaban guru perempuan MI untuk soal no. 3 seperti tertera pada gambar 11 berikut.

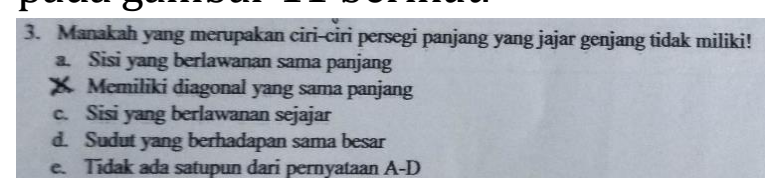

Gambar 11 Jawaban guru MI Perempuan untuk soal no. 3

Dari gambar terlihat guru MI perempuan memilih jawaban $B$. Wawancara kemudian dilakukan 
untuk mengetahui alasan pemilihan opsi B. Dari wawancara diperoleh informasi bahwa guru memilih jawaban B dikarenakan menurut guru tersebut jajar genjang memiliki diagonal yang tidak sama panjang.

Pernyataan guru tersebut sudah sesuai dengan apa yang dikemukakan oleh Musser, Burger, and Petterson. Musser, Burger, and Petterson (2011) mengungkapkan bahwa unsur persegi panjang yang tidak dimiliki jajar genjang antara lain: semua sudutnya siku-siku, setiap sisinya tegak lurus, dan diagonalnya sama panjang. Sementara ciri-ciri yang dimiliki persegi panjang yang juga dimiliki oleh jajar genjang antara lain: dua pasang sisi yang berhadapan sama panjang, dua pasang sisi yang berhadapan sejajar, dan diagonalnya berpotongan pada titik tengah bangun tersebut. Dikarenakan sudah menjawab dengan tepat maka guru perempuan MI tersebut telah memenuhi kriteria tingkat berpikir level 2. Muhsetyo (2007) menambahkan bahwa level berpikir tingkat 2 biasanya cocok digunakan untuk kelas 1 dan 2 SMP. Walaupaun untuk satuan pendidikan dasar yang mencakup SD/MI tidak diperlukan sampai tingkat berpikir level 2, namun hal ini juga sangat bermanfaat untuk membelajarkan siswa dalam persiapan olimpiade. Mengingat soal olimpiade SD/ MI justru kebanyakan memiliki tingkat kesulitan setara SMP ke atas.

Berdasarkan hasil tes diperoleh jawaban guru perempuan MI untuk soal no. 4 seperti tertera pada gambar 12 berikut

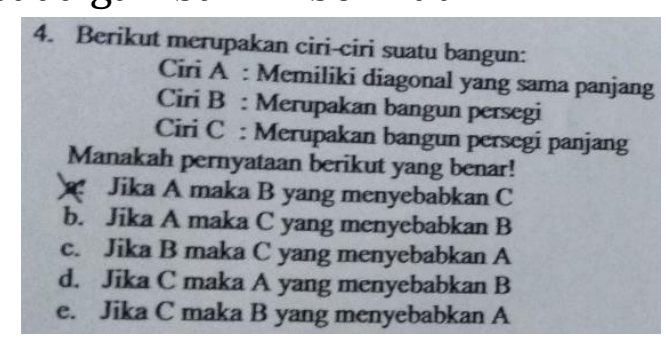

Gambar 12 Jawaban guru MI

Perempuan untuk soal no. 4

Dari gambar terlihat guru MI perempuan memilih jawaban A. Wawancara kemudian dilakukan untuk mengetahui alasan pemilihan opsi C. Dari wawancara diperoleh informasi bahwa guru memilih jawaban $\mathrm{C}$ dikarenakan ciri bangun yang memiliki diagonal sama terjadi pada bangun persegi yang kemudian disebabkan oleh bangun persegi panjang.

Pernyataan guru tersebut kurang sesuai dengan apa yang dikemukakan oleh Musser, Burger, and Petterson. Musser, Burger, and Petterson (2011) mengungkapkan bahwa persegi panjang dan persegi memiliki diagonal yang sama panjang. Hal yang tidak terdapat dalam pernyataan guru tersebut adalah bahwasanya ada hubungan antara persegi panjang dan persegi. Dalam Musser, Burger, and Petterson 
(2011) dijelaskan bahwa setiap unsur persegi panjang juga merupakan unsur dari persegi. Sedangkan terdapat unsur pada persegi yang bukan termasuk unsur pada persegi panjang seperti misalnya: sisi-sisi yang berdekatan sama panjang dan diagonalnya saling tegak lururs. Dari pernyataan-pernyataan tersebut dapat ditarik kesimpulan bahwa setiap persegi pasti merupakan persegi panjang sedangkan setiap persegi panjang belum tentu persegi. Dengan pernyataan tersebut jelaslan jika suatu bangun persegi maka bangun tersebut persegi panjang. Dikarenakan pada soal tersebut guru belum mampu menjawab dengan benar maka dapat ditarik kesimpulan bahwa guru MI perempuan tersebut belum memenuhi kriteria berpikir level 3. Sebenarnya dalam membelajarkan geometri pada MI guru tidak perlu sampai pada tahap level 3. Hal ini seperti yang dijelaskan oleh Muhsetyo (2007) bahwa level berpikir tingkat 3 cocok digunakan untuk siswa-siswi di SMA.

\section{Berdasarkan hasil tes} diperoleh jawaban guru perempuan MI untuk no. 5 seperti tertera pada gambar 13 berikut.

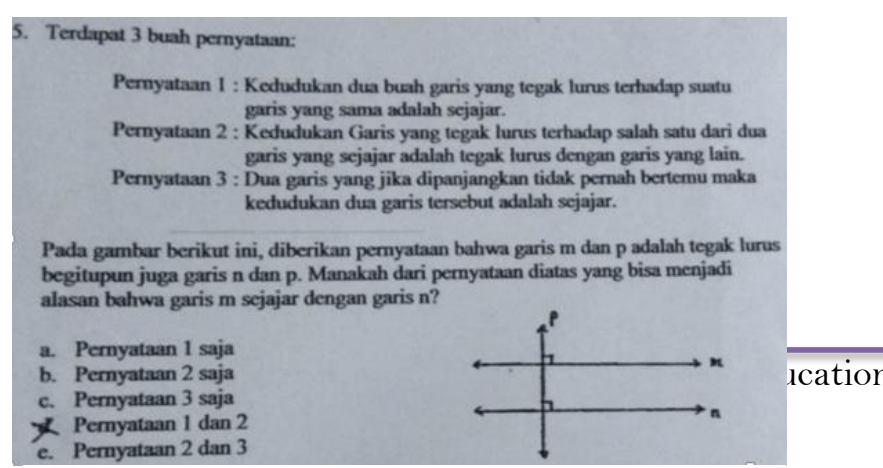

Gambar 13 Jawaban guru MI Perempuan untuk soal no. 5
Dari gambar terlihat guru MI perempuan memilih jawaban D. Wawancara kemudian dilakukan untuk mengetahui alasan pemilihan opsi D. Dari wawancara diperoleh informasi bahwa guru memilih jawaban D guru memiliki pendapat pernyataan 1 dan pernyataan 2 merupakan pernyataan yang mendukung suatu kesimpulan tentang kesejajaran garis.

Pernyataan guru tersebut sudah sesuai dengan kunci jawaban. Seperti diketahui bahwa memang benar bahwa dua buah garis sejajar jika dipanjangkan maka tidak pernah bertemu. Tetapi yang ditanyakan adalah pernyataan yang mendasari hal tersebut. Jika diperhatikan, terdapat kata kunci yang mendasari suatu pernyataan dijadikan landasan dalam kesejajaran. Dalam soal diketahui bahwa garis $m$ dan $p$ adalah tegak lurus begitupun juga garus $\mathrm{n}$ dan $\mathrm{p}$. Dua pernyataan itu yang sebenarnya menjadi alasan mengapa pernyataan 1 dan pernyataan 2 merupakan jawaban yang tepat. Pernyataan 3 tidak termasuk dikarenakan tidak sesuai dengan kata kunci yang diberikan di soal. Walaupun pernyataan subjek guru MI perempuan sudah sesuai dengan apa yang dikemukaan oleh para ahli. Guru belum bisa dikatakan memiliki level berpikir tingkat 4. Van Hielle mengemukakan bahwa 
Permanent link for this document : https://doi.org/10.33367/jiee.v1i1.682

Analisis Level Berpißir Geometri Guru MI Ditinjau dari Jenis Kelamin

Oleh: Muhammad Auzäi Aqib

tingkatan level tersebut juga memiliki sifat. Salah satunya adalah fixed sequence. Maksud dari fixed sequence adalah seseorang belum bisa dikategorikan berada pada level $\mathrm{n}$ tanpa melalui level $\mathrm{n}-1$ dahulu. Dikarenakan guru belum memenuhi kriteria level 3 maka dapat disimpulkan guru belum bisa dikatakan melewati level berpikir tingkat 4. Pada dasarnya guru tidak perlu berada pada level berpikir tingkat 4 untuk mengajarkan geometri di MI hal ini seperti yang dikemukakan oleh Musser, Burger, and Petterson (2011) bahwa level 4 tidak cocok diajarkan di jenjang dasar atau pun menengah tetapi sangat cocok jika diajarkan di jenjang perguruan tinggi.

\section{Kesimpulan}

Beberapa kesimpulan yang dapat peneliti kemukakan sebagai hasil dari penelitian ini adalah sebagai berikut:

1. Subjek guru MI laki-laki berada pada tingkat berpikir level 0 , dimana pada level 0 guru memahami bangun datar secara holistik tidak secara analitik. Hal ini mengindikasikan guru akan mudah mengajarkan geometri untuk kelas 1-2 SD/MI tetapi akan kesulitan jika mengajarkan geometri untuk kelas 3-6 SD/MI.
2. Subjek guru MI perempuan berada pada tingkat berpikir level2, dimana pada level 2 guru sudah memahami hubungan antar bangun secara abstrak. Hal ini mengindikasikan guru akan mudah mengajarkan geometri untuk kelas 1-6 SD/ MI.

\section{Saran}

Adapun saran-saran yang dikemukakan peniliti adalah sebagai berikut:

1. Pada dasarnya tingakatan level berpikir van hielle bisa meningkat, sehingga perlu adanya pembinaan bagi guru MI supaya pembelajaran yang dilakukan sesuai dengan level berpikir yang seharusnya didapatkan oleh siswa SD/MI.

2. Sebagai upaya tindak lanjut dari penelitian ini, perlu diadakan lagi penelitian serupa dengan tinjauan yang berbeda supaya hasil yang didapatkan lebih bervariasi.

\section{Daftar Pustaka}

Muhsetyo, G. (2007). Pembelajaran Matematika SD. Jakarta: Universitas Terbuka.

Musser, Burger, and Petterson (2011). Mathematics for Elementary Teahcer a contemporary approach. United State: John Wiley \& Sons, Inc.

Peraturan Menteri Pendidikan dan Kebudayaan Republik Indonesia. 
No. 4 Tahun 2018. Tentang Penilaian Hasil Belajar oleh Satuan Pendidikan dan Penilaian Hasil Belajar oleh Pemerintah.

Peraturan Menteri Pendidikan dan Kebudayaan Republik Indonesia. No. 19 Tahun 2016. Tentang Program Indonesia Pintar.

Pemerintah Indonesia. 2005. Undang-Undang RI Nomor 14 Tahun 2005 tentang Guru dan Dosen.

Shiel, G., Perkins R., Close S. \& E. Oldham. (2007). PISA Mathematics: A Teacher's Guide. Dublin: Department of Education and Science 